\title{
STRATEGIES TO DEVELOP FOOD CROP COMMODITY TO IMPROVE THE PROSPERITY OF RURAL FARMERS IN GROBOGAN DISTRICT
}

\author{
Avi Budi Setiawan and Sucihatiningsih Dian Wisika Prajanti \\ Semarang State University
}

\begin{abstract}
The policy strategy to develop the agricultural sector in Indonesia is important to be arranged as agriculture has various problems and needs a comprehensive policy. Many districts in Central Java are dominated by agriculture sector where agricultural becomes the basis for the economy. The agricultural sector therefore provides significant contribution towards economic structure and commodities' production. In terms of commodity, corn is the second biggest agricultural commodity after paddy in Grobogan district in Central Java, reflected by a huge demand of corn in the market. The strategy to develop corn farming in Grobogan district therefore needs to be dealt with various criteria and alternatives. This study will consider several aspects which have an important role in agricultural sector as strategies to develop food crop particularly corn commodity to improve the farmers' prosperity in Grobogan.
\end{abstract}

Keywords: Food Crop Commodity, Agriculture, Rural Farmers, Grobogan

JEL Classifications: $Q 12, Q 16$

\section{INTRODUCTION}

The development of agricultural sector in Indonesia needs to be accommodated in order to improve this sector in terms of the production, output, and quality as well as the prosperity of the farmers. Agriculture is therefore expected to have competitiveness particcularly to improve the welfare of farmers in both socially and economically aspects. The arrangement of policy strategy to develop farming sector needs to be provided considering the numerous farming problems in Indonesia which require comprehensive solutions. There are many production factors influencing the output of farming sector commodities that is necessary to have a clear identification to formulate a series of development policies in farming sector. 
The high production of farming and food crop commodities in Central Java is supported by the high contribution of each district/city of the region. The majority of districts in Central Java is dominated by agriculture sector where the farming sector is the main basis of the economy. As a consequence, the economic (agricultural) structures of the districts in Central Java directly contribute to the production of farming commodities. Agricultural areas which have a significant contribution to the farming commodity production are usually those with a relatively vast landmass and huge number of employment.

Grobogan is a district with the third biggest landmass in Central Java which consists of 18 sub-districts. This potential has made Grobogan as one of the food barns in Central Java, where most of their population work in this sector. Farming sector is also the biggest contributor of Grobogan district's Gross Regional Domestic Product (GRDP) from year to year. With the vast farming field, the availability of various production factors, massive output of farming sector, and the existence of various kinds of high-yield commodities (rice, corn, and soybean), the development of farming sector are vital to increase farming sector's competitiveness as well as farmers' prosperity.

Corn is the primary commodity of Grobogan district after rice or paddy, reflected by the high demand of corn in the agricultural market. Grobogan also serves as the backbone of corn production in Central Java. Farmers in Grobogan commonly plant corn annually if the field is an irrigated one; however, if it is a rain storage characterized, the planting is conducted twice a year. In addition, if farmers use the intercropping system in the forest, there will be three harvests conducted in a year. Corn itself is generally used for livestock provisions and people's consumption.

The significant contribution of corn commodity in Grobogan to the total production of farming commodity, makes Grobogan as one of the corn centres in the province, especially regarding the fact that it has the third largest landmass in Central Java. Nevertheless, the amount of Grobogan's GRDP is relatively low compared to other districts or cities. (BPS of Central Java Province: 2013). 
The immense potential of farming sector owned by Grobogan must be matched with the development strategies which are complex and applicative; supporting that corn is a superior commodity and the biggest contributor to the farming sector output in Grobogan. Besides, corn is the main plant grown by farmers in Grobogan.

Table 1 Corn centres distributed in 8 districts of Central Java in 2010

\begin{tabular}{|c|l|c|c|c|}
\hline \multicolumn{2}{|c|}{ District/City } & $\begin{array}{c}\text { Harvest Area } \\
\text { (hectares) }\end{array}$ & $\begin{array}{c}\text { Output/hectares } \\
\text { (kw) }\end{array}$ & $\begin{array}{c}\text { Production } \\
\text { (ton) }\end{array}$ \\
\hline 1. & Cilacap & 5,158 & 49.88 & 25,727 \\
\hline 2. & Wonogiri & 63,728 & 59.03 & 376,172 \\
\hline 3. & Banjarnegara & 24,305 & 41.88 & 101,788 \\
\hline 4. & Klaten & 11,226 & 52.77 & 59,242 \\
\hline 5. & Sragen & 13,763 & 47.94 & 65,974 \\
\hline 6. & Grobogan & 131,103 & 50.63 & 663,795 \\
\hline 7. & Blora & 59,250 & 46.11 & 273,231 \\
\hline 8. & Boyolali & 32,300 & 50.63 & 163,543 \\
\hline
\end{tabular}

Source: BPS of Central Java, 2010

The government supported with all of their elements related to the farming sector in Grobogan aims at improving the prosperity of corn farmers and increasing the output of corn farm; thus, a series of comprehensive strategies and policies are needed to develop the corn commodity. Strategic approach of developing corn farm in Grobogan should be focused on the society's wealth. This study, therefore, discusses the development strategy of corn farm which is conducted based on an analysis concerning choices of criteria and the alternatives of corn commodity development strategy.

The structure of this paper is as follows. The introduction presents the background and purpose of study. The second part explain the research methodology used. The third part discuss the results, while the last part concludes. 
Strategies to develop food commodity to Improve the prosperity of Rural Farmers in The District of Grobogan

\section{RESEARCH METHODOLOGY}

This study uses Analitycal Hierarchy Process (AHP) to determine the development strategy of corn commodity in Grobogan District. The AHP method is used to select criteria and alternatives to achieve the development of corn farm in Grobogan. The criteria and alternatives of the development strategy of crop farm used in AHP method in this study are as follows.

Table 2. Criteria and Alternatives in AHP method

\begin{tabular}{|c|c|}
\hline Criteria & Alternative \\
\hline \multirow{3}{*}{$\begin{array}{l}\text { Aspects of Production factors } \\
\text { (Input Provision) }\end{array}$} & Subsidy of production factor \\
\hline & $\begin{array}{l}\text { Investment of private party in providing production } \\
\text { factor }\end{array}$ \\
\hline & Provision of affordable production factor continuously \\
\hline \multirow[t]{3}{*}{ Cultivation Aspect } & Farmer supervisory \\
\hline & Stimulating organic fertilizer and organic pesticide \\
\hline & Stimulating the use of quality and labeled seeds \\
\hline \multirow[t]{3}{*}{ Aspect of Government Policy } & $\begin{array}{l}\text { Support in determining cost of goods sold policy } \\
\text { (Harga Pokok Penjualan/HPP) }\end{array}$ \\
\hline & Policy of infrastructure development \\
\hline & $\begin{array}{l}\text { Technical support (tools, production factor, training) } \\
\text { for farmers }\end{array}$ \\
\hline \multirow[t]{3}{*}{ Institutional Aspect } & $\begin{array}{l}\text { Training of institutional strengthening for farming } \\
\text { group }\end{array}$ \\
\hline & Incentive scheme for active farm \\
\hline & $\begin{array}{l}\text { Revitalization of Village Cooperation (Koperasi Unit } \\
\text { Desa/KUD) and training institutions }\end{array}$ \\
\hline \multirow[t]{2}{*}{ Post-Harvest Aspect } & Partnership between farmers and major enterprises \\
\hline & $\begin{array}{l}\text { Training and education regarding the effective post } \\
\text { harvest treatment. }\end{array}$ \\
\hline
\end{tabular}




\section{Sample}

In oder to formulate the strategy of developing corn farm using AHP, there are 10 respondents as sample with the assumption that they are the key persons who have a competence to become respondents. The determination on the number of sample (10 people) is based on the sample result sufficiency in which for the AHP selected respondents are those with the related competence.

In this study, specifically, the key persons employed as respondents are as follows: small scale farmers, large scale farmers, Department of Agriculture, the Regional Development Planning Board (Bappeda), the farming investigator, the UPTD of farming, trader of production factor (agent of fertilizer, seed, chemical preparation, and scolding), post-harvest enterprises, academics (farming observer), and farming group.

The descriptive qualitative analysis is used to complement and support the data in AHP or quantitative analysis. To obtain the information in the qualitative descriptive analysis, in depth interview and observation to farmers are conducted. This analysis is used particularly to sharpen the description about: (1) general description of the farming condition, (2) method of farm, and (3) strategy of farming commodity development policy.

The data used in this study therefore is both primary and secondary data. The primary data is obtained from direct interviews with the key persons related to corn commodity by using questionnaires. Meanwhile, the secondary data is the one obtained from records or other sources which are previously available and processed. The secondary data is obtained from BPS of Central Java, the Department of Food Crop Farming and Holticulture of Grobogan District, and records of farming reports of Grobogan District.

\section{RESULT AND DISCUSSION}

\section{Farmers' condition and farm in Grobogan District}

Farming is the sector which has become the main source of living for most people in Grobogan. In general, farmers in Grobogan grow paddy as the main commodity. The planting intensity depends on the field condition. If the field is an irrigated type, paddy can be planted twice a year, but if it is a rain reservoir field then it can only be planted once a 
year. Farmers in Grobogan mostly live in rural areas considering that farming sector grows and becomes the main support there.

The problems faced by farmers in Grobogan are relatively the same, i.e. the limited availability of subsidized fertilizer which is not balanced with the need of the farmers. This condition makes the farmers must use the other variant of fertilizer as substitute to meet the need of fertilizer during the planting season.

For corn commodity farmers specifically use hybrid seed to grow. They consider that hybrid corn is more suitable with and resistant to weather condition, can endure the dry, less water condition and can produce quality of harvest. The development of corn hybrid, "pioneer" is one type of corn grown by the majority of farmers. The first generation of hybrid corn is the type of pioneer 7 or called P7. It is then followed by the release of P11 type, while now farmers grow pioneer 21 of P 21 . This development of Pioneer hybrid corn seed is more about product innovation.

\section{Strategy to Develop Corn Farming in Grobogan The Development of Corn Commodity}

Corn farm characteristically has a different cultivation and marketing mechanism from other commodities. Analitycal Hierarchy Process is used to formulate the priority strategy in developing corn commodity in Grobogan. The formulation of alternative and priority is made to examine all possibilities which might play a role in the development of corn commodity.

The establishment of corn processing factories is also believed to bring solutions to improve farmers' wealth and develop corn commodity in the future. This is because corn processing factories will, at least, provide guarantee that the corn grown by the farmers will be bought at a proper price as long as it meets the required quality.

The selling price will also be better since it will be bought at the final product before it is converted into different commodities. For quality fulfillment task, it is the responsibility of farmers and farming groups with an appropriate supervisory. 
Based on the findings in table 3 , it is found that the production aspect factor (input provision) is the most important aspect and a priority in developing corn commodity (with a priority percentage as much as $39.2 \%$ ). The second most important criteria in developing corn commodity is the cultivation aspect with the priority percentage of $21.0 \%$. Next, the post-harvest aspect is the third priority criteria with the priority percentage of $20.3 \%$. The aspect of government policy is at the fourth position of priority (11.2\%). Lastly, the institutional aspect which is the last significant aspect among others with a percentage of $8.2 \%$.

Table 3. Priority Aspects of the Development of Corn Commodity

\begin{tabular}{|c|c|c|}
\hline Abbreviation & & Definition \\
\hline Goal & & The develonment od corn commoditv in arobonan \\
\hline FP & & Production factor aspect \\
\hline RI IDIDAYA & & Cultivation aspect \\
\hline KP & & Government bolicv aspect \\
\hline KFI FMRAG & & Imstitutional aspect \\
\hline $\mathrm{PP}$ & & Post-harvest aspect \\
\hline FP & 3.92 & \\
\hline RIIDIDAYA & 210 & \\
\hline $\mathrm{KP}$ & 112 & \\
\hline KFI FMRAG & ก८? & \\
\hline PP & 203 & \\
\hline & & Inconsistencv Ratio $=0.09$ \\
\hline
\end{tabular}

\section{Source: Authors' Calculations}

Based on the result analysis in table 3, it is found that the priority aspect that is necessary for the development of corn commodity is quite distinct with other types of food crop commodity. It does not stop in determining the aspects of criteria which become the priority, but each criterion has its alternatives of priority which support the efforts to develop corn commodity. Therefore, the calculation of priority alternative for each criterion is also conducted. 


\section{Production Factor Aspect (Input Provision)}

Production factor aspect (input provision) in corn commodity is the major aspect of priority, as shown in table 3. In determining the strategy of corn development in Grobogan, there are three alternatives from production factor (input provision), i.e. (1) subsidy of the production factor, (2) investment by private sector in the provision of production factor, and (3) a continuous provision of affordable production factor. The result is presented in table 4.

Table 4. Corn Commodity Development from the Production Factor Aspect

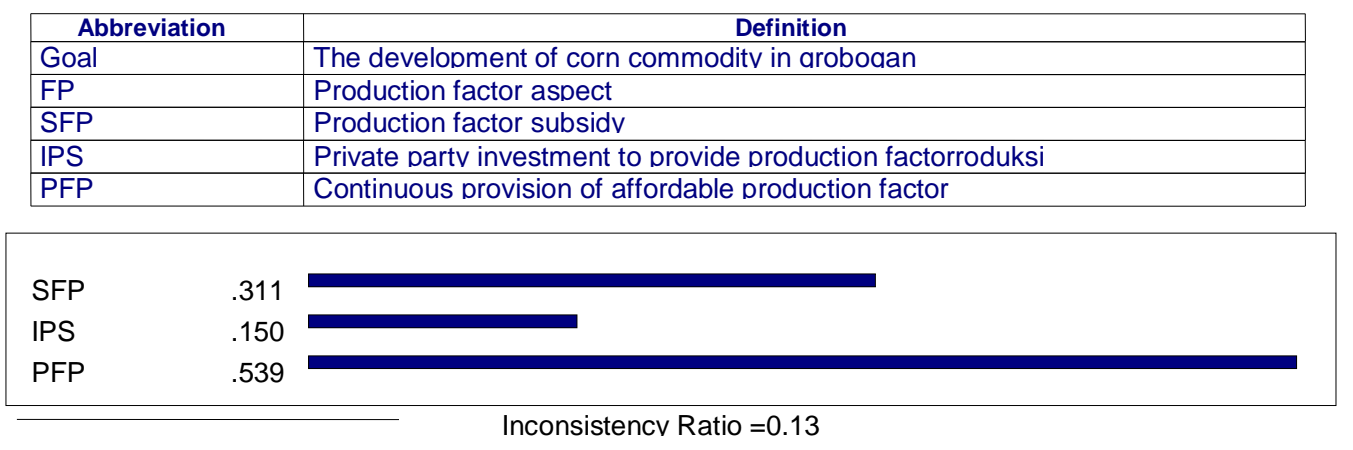

Source: Authors' Calculations

In terms of production factor, the strategy that becomes the priority is the continuous provision of affordable production factor with the percentage of 53.9\%. Then it is followed by the production factor subsidy with $31.1 \%$ and the investment by private sector to provide the production factor provision with $11.5 \%$.

\section{Cultivation Aspect}

As mentioned above, the cultivation aspect is the second priority of the five aspects discussed. The cultivation aspect itself has three alternatives, including (1) supervisory of farmers, (2) stimulating the use of organic fertilizer as well as pesticide, and (3) stimulating the use of quality and labelled seeds. Similarlarly to the previous aspect, they are then put in the order of importance based on the AHP analysis. The result is presented in table 5. 
Table 5. Priority of Corn Development from the Cultivation Aspect

\begin{tabular}{|l|l|}
\hline \multicolumn{1}{|c|}{ Abbreviation } & \multicolumn{1}{c|}{ Definition } \\
\hline Goal & Corn commodity development in grobogan \\
\hline BUDIDAYA & Cultivation aspect \\
\hline PKP & Supervisory for farmers \\
\hline MPO & Stimulating the use of organic fertilizer and pesticide \\
\hline MPB & Stimulating the use of quality and laelled seeds \\
\hline
\end{tabular}

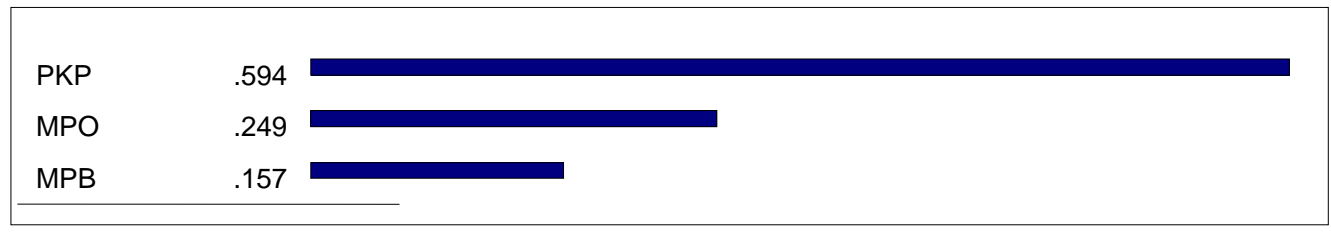

Inconsistency Ratio $=0.05$

Source: Authors' Calculations

Based on the result in table 5, the supervisory of farmers is the most prioritized alternative from the cultivation aspect with a percentage of $59.4 \%$. Supervisory of farmers is considered as high importance considering the need of farmers to be supported. The second important alternative is stimulating the use of organic fertilizer and pesticide , followed by stimulating the use of quality and labeled seeds with $24.9 \%$ and $15.7 \%$ respectively. These alternatives are believed to be representative in explaining the aspects of cultivation necessary to improve corn commodity.

\section{Post-Harvest Aspect}

The third aspect of priority is the post-harvest aspect. There are two alternatives in the post-harvest aspect which is considered, i.e. (1) partnership between farmers and major companies and (2) education and training on the effective post harvest treatment. By using AHP analysis, table 6 presents the alternative priority based on the post-harvest aspect. 
Strategies to develop food commodity to Improve the prosperity of Rural Farmers in The District of Grobogan

Table 6. Priority of Corn Commodity based on the Post-Harvest Aspect

\begin{tabular}{|l|l|}
\hline \multicolumn{1}{|c|}{ Abbreviation } & \multicolumn{1}{c|}{ Definition } \\
\hline Goal & The development of corn commodity in grobogan \\
\hline PP & Post-harvest aspect \\
\hline KPP & Farmers partnership with major companies \\
\hline PDE & Education and training on effective post-harvest treatmentt \\
\hline
\end{tabular}

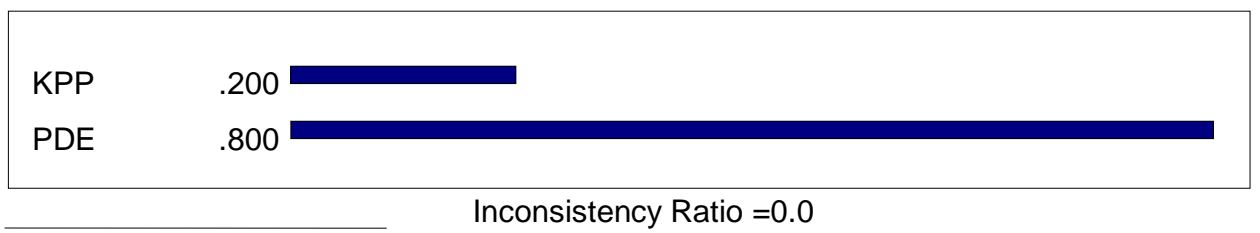

Source: Authors' Calculations

Based on table 6, education and training for farmers regarding the effective postharvest treatment becomes the most important alternative with the highest percentage (80.0\%). Meanwhile, farmers' partnership with major companies only gets priority percentage as much as $20.0 \%$.

\section{Government Policy Aspect}

In government policy aspect, which is the fourth most important aspect, there are three alternatives, including (1) support of cost of goods sold policy (Harga Pokok Penjualan/HPP), (2) the development of infrastructure policy, and (3) technical support for farmers. The AHP result from government policy aspect is presented in table 7. 
Table 7. Priority of Corn Commodity based on Government Policy Aspect

\begin{tabular}{|l|l|}
\hline \multicolumn{1}{|c|}{ Abbreviation } & \multicolumn{1}{c|}{ Definition } \\
\hline Goal & The development of corn commodity in grobogan \\
\hline KP & Government policy aspect \\
\hline HPP & Support of policy in determining the cost of goods sold (HPP) \\
\hline KPI & Infrastructure establishment policy \\
\hline BT & Tdchnical support for farmers \\
\hline
\end{tabular}

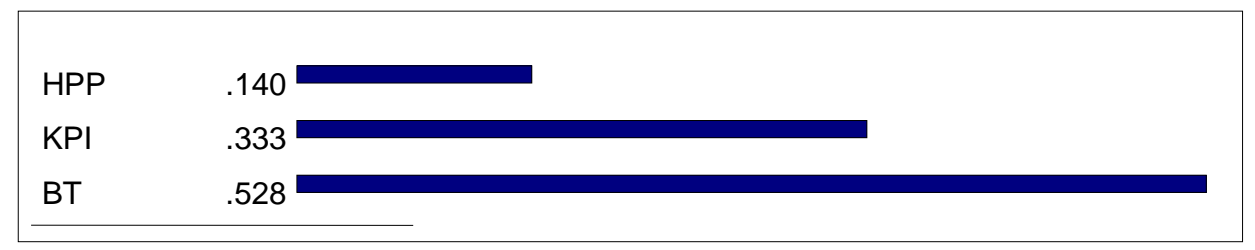

Inconsistency Ratio =0.05

Source: Authors' Calculations

Based on the AHP result, presented in table 7, it can be informed that the pricing policy (cost of goods sold/HPP) is the alternative which is least prioritized, with the percentage of $14.0 \%$. The second most important alternative is the policy of infrastructure development with $33.3 \%$. For the most important alternative, technical support for farmers is prioritized with the percentage of $52.8 \%$. The technical support includes provision of tools for farming and the provision of the production factor.

\section{Institutional Aspect}

The institutional aspect is the last priority aspect in the developing corn foodcrop commodity in Grobogan. This institutional aspect is divided into three alternatives, i.e. (1) institutional strengthening of farming group, (2) incentive scheme for active farming institution, and (3) revitalization of cooperation (KUD) as well as training institutions. Table 8 presents is the AHP result regarding the alternatives of the institutional aspect. 
Table 8. Priority of Corn Commodity Development from the Institutional Aspect

\begin{tabular}{|l|l|}
\hline \multicolumn{1}{|c|}{ Abbreviation } & \multicolumn{1}{c|}{ Definition } \\
\hline Goal & The development of corn commodity in grobogan \\
\hline KELEMBAG & Institutional aspect \\
\hline PK & Training on institutional strengthening of farming group \\
\hline IBT & Incentive scheme for active farming institutions \\
\hline KUD & Revitalization of KUD (rural cooperative unit) and training institutions \\
\hline
\end{tabular}

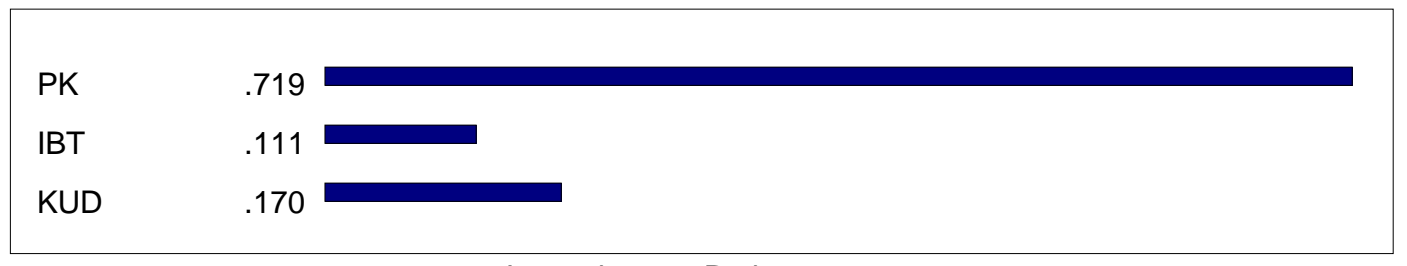

Inconsistency Ratio $=0.07$

Source: Authors' Calculations

Table 8 shows that training to strengthen the farming group institutions is the most important alternative compared to the ather two aspects with the percentage of $71.9 \%$. The second and third position of alternative are revitalization of KUD and training institution, and incentive scheme for active institution with the percentages of $17.0 \%$ and $11.1 \%$ respectively.

\section{The Rank of Priority Strategy Alternative for the Corn Commodity Development}

Each specific aspects (there are 14 alternatives altogether) is further compiled together and is ranked from the most important (most vital) until the least important strategy for the corn commodity development. The rank of priority is presented in table 9 based on the AHP analysis.

As presented in table 9, the continuous provision of affordable production factor is the alternative with the highest priority in the strategy of developing food crop (corn) commodity in Grobogan with a percentage of $23.6 \%$. It is then followed by subsidy of production factor $(13.6 \%)$ and supervisory of farmers $(12.7 \%)$. Both in the second and third rank consecutively. Meanwhile, the alternatives which are not considered as priority include the policy of determining the cost of goods sold (HPP) with a priority percentage of only 1.8\%, revitalization of KUD and training institutions (1.2\%), and the incentive scheme for active farming groups with a percentage of only $0.8 \%$. 
Table 9 The Rank of Priority Strategy Alternative to Develop Corn Commodity

\begin{tabular}{|c|l|c|}
\hline Priority & \multicolumn{1}{|c|}{ Alternative } & Percentage \\
\hline 1 & Continuous provision of affordable production factor & $23.6 \%$ \\
\hline 2 & Subsidy of production factor & $13.6 \%$ \\
\hline 3 & Supervisory for farmers & $12.7 \%$ \\
\hline 4 & Education and training on effective post-harvest treatment & $12.2 \%$ \\
\hline 5 & Technical support (tools, production factor, training) for & $6.8 \%$ \\
\hline 6 & farmers & $6.5 \%$ \\
\hline 7 & Investment by private party in the provision of production \\
\hline 8 & Training on institutional strengthening of farming group & $5.3 \%$ \\
\hline 9 & policy of infrastructure development & $4.9 \%$ \\
\hline 10 & Stimulating the use of quality and labeled seed & $4.3 \%$ \\
\hline 11 & Farmers' partnership with major industries & $3.4 \%$ \\
\hline 12 & Policy support in determining the cost of goods sold (HPP) & $1.8 \%$ \\
\hline 13 & Revitalization of KUD and training bodies & $1.2 \%$ \\
\hline 14 & Incentive sheme for active farming groups & $0.8 \%$ \\
\hline & & $\mathbf{1 0 0} \%$ \\
\hline
\end{tabular}

Source: Authors' Calculations

\section{CONCLUSION}

The strategies to develop corn farm based on the order of prioritized criteria of development are as the following: (1) the production factor, (2) cultivation, (3) postharvest, (4) government policy, and (5) institutional aspect. Farmers then are expected to have better ability in using and utilizing the production factors owned proportionally, making it more efficient and beneficial. All of this ability can be done by learning about the methods in farm. This is also closely related to the technical aspect of cultivation. Farmers are required to be more creative or innovative in doing their farm for example using 
organic fertilizer which is safe to be used in soil, willing to learn new knowledge given to them, and changing the old mindset of farmers.

A continuous provision of affordable production factors, the giving of subsidy, and protection for farmers in terms of price like the policy on cost of goods sold should be improved considering these points are urgent priorities. The establishment of corn processing factories is also considered as offering solutions in improving the farmers' prosperity and developing corn commodity in the future. This is because the corn processing factories will give, at least, a guarantee that the corn grown will be bought at reasonable price as long as it can meet the required quality.

\section{REFERENCES}

Arikunto, S. (2002). Prosedur Penelitian : Suatu Pendekatan Praktek. Jakarta : Rineka Cipta.

Arsyad, L. (2004). Ekonomi Pembangunan. Yogyakarta : STIE YKPN

Baehaqi, A. (2007). Pengembangan Komoditas Unggulan Tanaman Pangan di Kabupaten Lampung Tengah. Tesis, Institut Pertanian Bogor

Setiawan, A. B. (2008). Analisis Efisiensi Penggunaan Faktor-faktor Produksi Usahatani Jagung Di Kabupaten Grobogan tahun 2008, Skripsi, UNNES

Badan Bimas Ketahanan Pangan. (2001). Rencana Strategis dan Program Kerja Pemantapan Ketahanan Pangan 2001-2004. Badan Bimas Ketahanan Pangan. Jakarta.

BPS Provinsi Jawa Tengah (2007), Jawa Tengah Dalam Angka: Jawa Tengah.

BPS Provinsi Jawa Tengah (2009), Jawa Tengah Dalam Angka: Jawa Tengah.

BPS Kabupaten Grobogan (2007). Grobogan Dalam Angka: Grobogan

BPS Kabupaten Grobogan (2008). Grobogan Dalam Angka: Grobogan

Dinas Pertanian dan Perkebunan Kabupaten Grobogan (2007), Luas Panen dan Produksi Tanaman Jagung Tahun 2002-2007: Grobogan.

Dinas Pertanian dan Perkebunan Kabupaten Grobogan (2006), Petunjuk Pelaksanaan Program intensifikasi Tanaman pangan dan perkebunan. Grobogan.

Mason, R.D., (1996), TeknikStatistika untuk Bisnis dan Ekonomi, Jakarta: Erlangga

Mosher, A.T., (1978), An Introduction to Agricultural Extension, Agricultural Development Council, New York

Mosher, A.T (1985). Menggerakkan dan Membangun Pertanian Saduran Krisnandhi C.V. Yasaguna, Jakarta. 
Mubyarto (1989), Pengantar Ekonomi Pertanian, Jakarta : LPES.

Nicholson, W. (2002), Mikro Ekonomi Intermediate. Jakarta. Erlangga

Permadi, B. (1992). Analysis Hierarchy Process. Jakarta. PAU EK Universitas Indonesia

Saaly, T.L. (1987). The Analytic Hierarchy Process- What it is and How it is used, Math Modelling, Pergamon Journals Ltd. Great Britain

Situs Resmi Pemerintah Kabupaten Grobogan. http://www.grobogankab.go.id.

Situs Resmi Pemerintah Provinsi Jawa Tengah. http://www.jawatengah.go.id.

Soekartawi (2003). Teori Ekonomi Produksi Dengan Pokok Bahasan Analisis Fungsi CobbDouglas (Theory of Production Economics with Special Discussion on Cobb-Douglas Production Function). 3rd Edition, Raja Grafindo Persada, Jakarta.

Sukirno,S. (2005), Mikro Ekonomi Teori Pengantar, Raja Grafindo Persada: Jakarta

Sucihatiningsih, DWP, (2010) .Model Penguatan Kapasitas Kelembagaan Penyuluh Pertanian dalam Meningkatkan Kinerja Usaha Tani:Studi Empiris di Provinsi Jawa Tengah . Disertasi. UNDIP

Suryana, Sawa, (2007). Analisis Faktor-faktor yang Mempengaruhi Produksi Jagung di Kabupaten Blora (Studi Kasus Produksi Jagung Hibrida di Kecamatan Banjarejo Kabupaten Blora). Tesis. UNDIP

Susilowati, I, Mudjahirin T. W, , Tri Winarni A, Agung S. (2004). Pengembangan Model Pemberdayaan Usaha Mikro Kecil, Menengah dan Koperasi Dalam Mendukung Ketahanan Pangan di Kabupaten dan Kota Pekalongan. RUKK Kantor Menneg Ristek dan LIPI. Jakarta.

Susilowati, I. (2009). Penguatan Kinerja Agribisnis Tanaman Pangan Unggulan Provinsi Jawa Tengah dalam Mendukung Ketahanan Pangan.Penelitian Sosial Ekonomi Pertanian. Kerjasama UNDIP dan Badan Litbang. Deptan.

Syahyuti. (1995). Pendekatan Kelompok dalam Pelaksanaan Program/Proyek Pembangunan Pertanian. Majalah Forum Agro Ekonomi. Vol. 13. No. 2 Desember 1995.

Syahyuti. (2002). Pembentukan Struktur Agraria pada Masyarakat Pinggiran Hutan. Tesis pada Jurusan Sosiologi Pedesaan. IPB, Bogor

Syahyuti. (2003). Pembangunan pertanian indonesia dalam pengaruh kapitalisme dunia: analisis ekonomi politik perberasan. Pusat penelitian dan pembangunan sosial ekonomi pertanian.

Vu. L. H. (2004). Efficiency of Rice Farming Households in Vietnam:a DEA with Bootstrap and Stochastic Frontier Application. University of Minnesota. USA

Yotopoulos, P. A and J. B Nugget. (1976), Economic of Development: Empirical Investigation, Harper International. USA

Yulianik, S. (2006). Analisis Efisiensi penggunaan Faktor-faktor Produksi pada Usahatani Bawang Merah di Kabupaten Brebes (Studi Kasus di Desa larangan). Skripsi. UNDIP 